\title{
Model Spasial Autoregresif (SAR) Durbin pada Anak Putus Sekolah (APS) yang Mengikuti Ujian Paket C Jenjang SMA Sederajat di Kota Makassar
}

\author{
Nurahdawati, Ruliana, \& Ansari Saleh Ahmar* \\ Program Studi Statistika, Fakultas Matematika dan Ilmu Pengetahuan Alam, Universitas Negeri Makassar, Indonesia
}

Keywords: School Dropouts (APS), Spatial Autoregressive (SAR) Durbin Model.

\begin{abstract}
:
This research is applied statistical research which aims: (i) To find out the average number of school dropouts (APS) taking the C exam package of high school level in Makassar City; (ii) To find out the SAR Durbin Model of school dropouts (APS) taking the C exam package of high school level in Makassar City; and (iii) To determine the factors that influence of school dropouts (APS) taking the $\mathrm{C}$ exam package of high school level in Makassar City. This study used SAR Durbin method (Spatial Autoregressive Durbin method). The results of this study are: (i) APS taking the C exam package of high school level in Makassar City; there are spatial dependencies between sub-districts one with the other unit sub-districts; (ii) APS taking the C exam package of high school level in Makassar City, and (iii) APS taking the C exam package of high school level in Makassar City with the results of the analysis Spatial Durbin Model obtained predictor variables, namely the School Teacher Ratio (X2), and amount of school (X5). While the spatial Lag parameter is obtained by the predictor variable namely Lag School Student Ratio (X1), Lag Poverty level (X4), and Lag amount of school (X5).
\end{abstract}

\section{Pendahuluan}

Pendidikan merupakan suatu elemen yang sangat penting untuk masa depan seluruh bangsa, semakin maju pendidikan maka semakin meningkat kesejahteraan masyarakat. Seberapa jauh usaha pemerintah dalam memajukan sektor pendidikan dapat dilihat melalui salah satu indikator yang seberapa besar keberhasilan pada bidang pendidikan. Dengan adanya pendidikan, anak-anak diasah melalui seperangkat pengetahuan untuk memiliki kesadaran dan kemauan yang positif dalam menemukan dan merumuskan tujuan untuk dirinya di masa-masa mendatang sesuai dengan tujuan pendidikan nasional yang ditetapkan undang-undang nomor 20 tahun 2003 tentang sistem Pendidikan Nasional (UU Sisdiknas, 2003).

Salah satu indikator untuk mengukur keberhasilan program pembangunan pendidikan yang diselenggarakan dalam rangka memperluas kesempatan bagi penduduk untuk mengenyam pendidikan. Tetapi masih banyak anak di Indonesia yang putus sekolah. Anak putus sekolah (APS) didefinisikan sebagai mereka yang pernah bersekolah di salah satu tingkat pendidikan, tetapi pada saat survey berlangsung mereka tidak terdaftar di salah satu tingkat pendidikan formal dan mengikuti ujian Paket C (Septiana \& Wulandari, 2012). Kita ketahui bahwa dari nilai APS di Kota Makassar pada tahun 2015-2016 mencapai 2.159 anak dan pada tahun 2016-2017 turun tingkat mencapai 1.384 anak (Kemdikbud, 2017). Dalam penelitian ini yang di maksud APS yang dimana dapat mengikuti ujian paket C pada sekolah Non-formal karena sudah tetapkan pendidikan wajib belajar..

\footnotetext{
* Corresponding author.

E-mail address: ansarisaleh@unm.ac.id
} 
Berdasarkan penelitian tentang APS di Kecamatan Jangka, Kabupaten Bireun, Provinsi Nanggro Aceh Darussalam secara umum masalah utamanya adalah kondisi ekonomi keluarganya (Grahacendikia, 2009). Hasil penelitian diwilayah Provinsi Jawa Tengah, kepadatan penduduk merupakan salah satu faktor yang juga mempengaruhi tingginya angka putus sekolah (Devitasari, 2017).

Dari beberapa penelitian sebagaimana yang telah diuraikan di atas maka dapat disimpulkan begitu tinggi angka APS yang dipengaruhi oleh beberapa faktor. Dalam penelitian ini dilakukan analisis dari faktor-faktor yang mempengaruhi tingkat APS, salah satu faktornya yaitu pembagian wilayah-wilayah atau perkecamatan dalam sekolah jenjang SMA sehingga peneliti menggunakan model Spasial Autoregressive Durbin. Penelitian ini mengambil lima faktor yang mempengaruhi tingkat APS yaitu rasio terhadap jumlah guru dan sekolah, rasio terhadap jumlah murid dan sekolah, angka buta huruf, tingkat kemiskinan dan jumlah sekolah.

Dari beberapa faktor-faktor yang mempengaruhi APS yang saling berhubungan antara faktor lainnya maka penelitian ini menggunakan analisis regresi. Model Regresi merupakan suatu model yang digunakan untuk mengetahui pola hubungan antara dua atau lebih variabel, yang dimana obyek penelitiannya adalah APS jenjang SMA sederajat di setiap Kecamatan di Kota Makassar. Untuk mengetahui faktor-faktor yang mempengaruhi APS, banyak penduduk yang sekolah di lingkungan atau kondisi geografis daerahnya dan daerah sekitanya. Dengan adanya letak geografis ini maka faktor wilayah ikut diperhitungkan. Oleh sebab itu, maka digunakan model regresi spasial yang merupakan pengembangan dari analisi regresi linier (Anselin, 1998).

Model Spasial Durbin merupakan model regresi spasial yang dikembangkan oleh (Anselin, 1998). Model ini menggunakan data spasial sebagai pendekatannya. Salah satu jenis matriks pembobot spasial yang digunakan adalah $K$-Nearest Neighbor yang didasarkan baris $i$ dalam matriks pembobot spasial menurut $k$ tetangga terdekat memiliki $k$ buah kolom $j$ dalam elemen 1 dan kolom lainnya bernilai 0 .

Pada model Spasial Autoregresif (SAR) yang digunakan, karena pengaruh lag spasial yang ikut diperhitungkan hanya ada variabel dependen saja. Sedangkan pada Model Spasial Durbin, pengaruh lag spasial yang diperhitungkan tidak hanya pada variabel dependen saja, namun juga pada independen.

\section{Tinjauan Pustaka}

\subsection{Model Regresi Klasik}

Analisis regresi merupakan alat statistik yang banyak digunakan dalam bidang. Analisis tersebut bertujuan untuk mengetahui hubungan antara variabel dependen dan variabel independen. Ada tiga macam tipe dari analisis regresi, tipe yang pertama adalah regresi linear sederhana yang berfungsi untuk mengetahui hubungan linear antara dua variabel, satu variabel dependen dan satu variabel independen. Tipe kedua adalah regresi linear berganda yang merupakan model regresi linier dengan satu variabel dependen dan lebih dari satu variabel independen. Tipe ketiga adalah regresi non linear yang berasumsi bahwa hubungan antara variabel dependen dan independen tidak linear pada parameter regresinya.

Persamaan regresi berganda adalah persamaan regresi dengan satu peubah dependen $(\mathrm{Y})$ dengan lebih dari satu peubah independen $\left(\mathrm{X}_{1}, \mathrm{X}_{2}, \ldots, \mathrm{X}_{\mathrm{n}}\right)$ (Anselin,1988). Hubungan antara peubah-peubah tersebut dapat dirumuskan dalam bentuk model (Anselin, 1988):

$$
\mathrm{Y}_{\mathrm{i}}=\beta_{0}+\beta_{1} X_{\mathrm{i} 1}+\beta_{2} X_{\mathrm{i} 2}+\cdots+\beta_{v} X_{i v}+\varepsilon_{\mathrm{i}} ; \operatorname{dimana}\{\mathrm{i}=1,2,3 \ldots, \mathrm{n}\}
$$

Dimana $\beta_{0}$ merupakan konstanta dan $\beta_{n}$ merupakan koefisien regresi peubah independen ke $n$. Bila dituliskan dalam bentuk matriks :

Asumsi-asumsi yang mendasari model regresi adalah:

$$
\mathbf{Y}=\mathbf{X} \boldsymbol{\beta}+\boldsymbol{\varepsilon}
$$

a. $\quad \varepsilon_{i}$ memiliki ragam homogen atau disebut juga tidak ada masalah heteroskedastisitas.

b. $\varepsilon_{i}$ dan $\varepsilon_{j}$ tidak berkorelasi, $i \neq j$ sehingga $\operatorname{cov}\left(\varepsilon_{i}, \varepsilon_{j}\right)=0$.

c. $\varepsilon_{i}$ merupakan peubah acak normal dengan nilai tengah nol dan ragam $\sigma^{2}$. Dengan kata lain, $\varepsilon_{i} \sim N\left(0, \sigma^{2}\right)$. 
Nilai dugaan bagi $\boldsymbol{\beta}$ diperoleh dengan menggunakan metode jumlah kuadrat terkecil, yaitu dengan meminimumkan $\sum_{i=1}^{n} \varepsilon_{i}^{2}$, sehingga nilai dugaan $\beta$ bagi yaitu:

$$
\overline{\boldsymbol{\beta}}=\left(\mathbf{X}^{\mathrm{T}} \mathbf{X}\right)^{-1} \mathbf{X}^{\mathrm{T}} \mathbf{Y}
$$

\subsection{Model Regresi Spasial}

Regresi Spasial merupakan suatu metode untuk memodelkan suatu data yang memiliki unsur spasial. Model umum regresi spasial atau juga biasa disebut Spatial Autoregressive Moving Average (SARMA) dalam bentuk matriks (LeSage, 1999) dapat disajikan sebagai berikut:

$$
\begin{aligned}
& \mathbf{Y}=\rho \mathbf{W Y}+X \boldsymbol{\beta}+\boldsymbol{u} \\
& \mathbf{u}=\boldsymbol{\lambda} \mathbf{W} \mathbf{u}+\boldsymbol{\varepsilon} \\
& \boldsymbol{\varepsilon} \sim N\left(0, \sigma^{2}\right)
\end{aligned}
$$

Dimana :

$$
\begin{aligned}
& \mathrm{Y}=\text { vektor variabel dependen dengan ukuran } x k \\
& \mathbf{X}=\text { matriks variabel independen dengan ukuran } n \times(k+1) \\
& \boldsymbol{\beta}=\text { vektor koefisien parameter regresi dengan ukuran }(k+1) \times 1 \\
& \rho=\text { parameter koefisien spasial lag variabel dependen } \\
& \lambda=\text { parameter koefisien spasial lag pada error } \\
& \mathbf{u}, \boldsymbol{\varepsilon}=\text { vektor error dengan ukuran } n \times 1 \\
& \mathbf{W}=\text { matriks pembobot dengan ukuran } n_{n=} \times \text { jumlah amatan atau lokasi } \\
& \mathbf{k}=\text { jumlah variabel independen }(\mathrm{k}=1,2, \ldots, 1) \\
& \mathbf{I}=\text { matriks identitas dengan ukuran } n \times n
\end{aligned}
$$

$\varepsilon_{i}$ diasumsikan menyebar normal, bebas stokastik, identik, dengan nilai tengah nol dan ragam $\sigma^{2}{ }_{s} \varepsilon_{i}$ adalah sisaan pada lokasi ke- $i$. Pengujian asumsi pada regresi spasial meliputi asumsi kehomogenan ragam dan kenormalan galat. Anselin (1988) mengatakan bahwa untuk menduga parameter regresi model spasial diperoleh dengan metode pendugaan kemungkinan maksimum.

\subsection{Model Autoregressif (SAR)}

Model Spatial Autoregressive (SAR) atau Spatial Lag Model (SLM) adalah model yang mengkombinasikan model regresi linier dengan lag spasial pada variabel respon dengan menggunakan data cross section (Anselin, 1988). Spasial lag muncul saat nilai observasi variabel respon pada suatu lokasi berkorelasi dengan nilai observasi variabel respon di lokasi sekitarnya atau dengan kata lain terdapat korelasi spasial antar variabel respon. Pada model ini terdapat fungsi dari variabel respon pada lokasi ke- $j$ yang digunakan sebagai variabel prediktor untuk memprediksi nilai dari variabel pada lokasi ke- $i$.

Model SAR merupakan model regresi linier yang pada peubah responnya terdapat korelasi spasial (Anselin, 1999). Model umum untuk SAR adalah sebagai berikut:

$$
\begin{aligned}
& \mathbf{Y}=\boldsymbol{\rho} \mathbf{W Y}+\mathbf{X} \boldsymbol{\beta}+\boldsymbol{\varepsilon} \\
& \boldsymbol{\varepsilon} \sim N\left(0, \sigma^{2} \mathbf{I}\right)
\end{aligned}
$$

Parameter lag spasial $(\rho)$ menunjukkan tingkat korelasi pengaruh spasial dari suatu wilayah terhadap wilayah lain disekitarnya. 
Pada persamaan $\hat{\sigma}=\frac{\varepsilon^{T_{\varepsilon}}}{n}, \quad \varepsilon$ diasumsikan menyebar normal, bebas stokastik, identik, dengan nilai tengah nol dan ragam $\sigma^{2}, \varepsilon_{i}$ adalah sisaan pada lokasi ke-i.

Pendugaan $n$ untuk sisaan ( $\boldsymbol{\varepsilon}$ ) (Anselin, 1998) adalah sebagai berikut:

$$
\begin{aligned}
& Y=\rho W Y+X \beta+\varepsilon \\
& (I-\rho W) Y=X \beta+\varepsilon \\
& \varepsilon=(I-\rho W) Y-X \beta
\end{aligned}
$$

Dengan $\rho$ adalah koefisien autoregresif lag spasial dan $\mathbf{W}$ adalah matriks pembobot spasial dengan ukuran $(n \times n), \mathbf{y}$ merupakan vektor peubah respon berukuran $(n x 1), \mathbf{X}$ merupakan matriks peubah penjelas berukuran $(n x k), \boldsymbol{\beta}$ merupakan vektor parameter yang akan diduga dengan ukuran $(k x 1)$, dan $\varepsilon$ adalah vektor galat model berukuran $(n x 1)$.

Fungsi kepekatan peluang adalah :

$$
f\left(\varepsilon_{i}\right)=\frac{1}{\sigma \sqrt{2 \pi}} \exp \left[\frac{\varepsilon i^{2}}{2 \sigma^{2}}\right],-\infty<\varepsilon_{i}<\infty
$$

Fungsi kepekatan peluang dari peubah respon adalah sebagai berikut :

$$
f\left(y_{1}, y_{2}, \ldots, y_{n}\right)=f\left(\varepsilon_{1}\right) \cdot f\left(\varepsilon_{2}\right), \ldots f\left(\varepsilon_{n}\right)\lfloor J\rfloor
$$

Dengan J adalah Jacobain dari sisaan. Penduga parameter dilakukan dengan memaksimumkan fungsi likelihood dibawah ini :

$$
\begin{aligned}
L\left(\beta_{v} \rho_{v} \sigma^{2}{ }_{s} y\right) & =f\left(y ; \beta_{s} \rho_{s} \sigma^{2}\right) \\
& =\frac{\|\boldsymbol{I}-\rho \boldsymbol{W}\|}{(2 \pi)^{\frac{n}{2}} \sigma^{n}} \exp \left[-\frac{\boldsymbol{e}^{T} \boldsymbol{e}}{2 \sigma^{2}}\right]
\end{aligned}
$$

\subsection{Model Spasial Durbin (SDM)}

Salah satu kekurangan dari model lag spasial adalah bahwa pola spasial dalam data hanya dapat dijelaskan oleh pengaruh interaksi peubah tak bebas, tetapi tidak dapat dijelaskan oleh pengaruh interaksi peubah bebas pada waktu yang sama. Model lag spasial dapat dikembangkan dengan model lag spasial peubah bebas yang dikenal sebagai Model Spasial Durbin. Model Spasial Durbin adalah model regresi spasial yang memiliki lag spasial pada variabel dependen (Y) dan variabel independen (X). Menurut (LeSage,1999) model spasial Durbin dinyatakan dengan persamaan sebagai berikut :

Atau bisa dituliskan sebagai berikut:

$$
\mathbf{Y}=\rho \boldsymbol{W} \mathbf{Y}+\boldsymbol{\beta}_{0}+\mathbf{X} \boldsymbol{\beta}_{1}+\boldsymbol{W} \mathbf{X} \boldsymbol{\beta}_{2}+\boldsymbol{\varepsilon}
$$

$$
\begin{aligned}
& \mathbf{Y}=\rho \mathbf{W} \mathbf{Y}+\mathbf{Z} \boldsymbol{\beta}+\boldsymbol{\varepsilon} \\
& \mathbf{Y}-\rho \boldsymbol{W} \mathbf{Y}=\mathbf{Z} \boldsymbol{\beta}+\boldsymbol{\varepsilon} \\
& (\mathbf{I}-\rho \mathbf{W}) \mathbf{Y}=\mathbf{Z} \boldsymbol{\beta}+\boldsymbol{\varepsilon} \\
& \boldsymbol{\varepsilon}=(\mathbf{I}-\rho \mathbf{W}) \mathbf{Y}-\mathbf{Z} \boldsymbol{\beta}
\end{aligned}
$$


Dengan $\boldsymbol{y}$ adalah vektor variabel dependen, $\boldsymbol{X}$ adalah matriks variabel independen berukuran $n \times(k+1), \rho$ adalah koefisien lag spasial variabel dependen, $\boldsymbol{\beta}_{\mathbf{0}}$ Adalah intersep $\boldsymbol{\beta}_{\mathbf{1}}$ merupakan parameter regresi tanpa pembobotan, $\boldsymbol{\beta}_{2}$ merupakan parameter regresi dengan pembobotan secara lokasi dan mendefinisikan $\mathbf{A}=(\mathbf{I}-\rho \mathbf{W}), \boldsymbol{W}$ adalah matriks pembobot spasial terstandarisasi berukuran $n \times n$ dan $\boldsymbol{\varepsilon}$ adalah vektor eror. Menurut Esa (2016) secara sederhana, model durbin dapat ditulis seperti model SAR dengan mengganti matriks $\mathbf{X}$ pada model SAR dengan $\mathbf{Z}=$ $[\mathbf{X}, \mathbf{W X}]$. Fungsi kepekatan peluang dari galat yang menyebar normal dengan nilai harapan nol dan ragam $\sigma^{2}$, sebagai berikut:

$$
f\left(\boldsymbol{\varepsilon}_{i}\right)=\frac{1}{\sigma \sqrt{2} \pi} \exp \left(-\frac{\boldsymbol{\varepsilon}_{i}}{2 \sigma^{2}}\right)
$$

Maka dapat diperoleh fungsi kepekatan peluang bersama galat adalah:

$$
\begin{aligned}
& f(\varepsilon)=\left(\varepsilon_{1}\right),\left(\varepsilon_{2}\right),\left(\varepsilon_{3}\right), \ldots,\left(\varepsilon_{n}\right) \\
& f(\varepsilon)=\frac{\exp \left(-\frac{\varepsilon^{\prime} \varepsilon}{2 \pi^{2}}\right)}{\left(\sigma^{2} 2 \pi\right)^{n / 2}}
\end{aligned}
$$

Fungsi kepekatan peluang dari peubah respon adalah sebagai berikut:

dengan,

$$
f(y)=f(\varepsilon)|\boldsymbol{J}|
$$

$|\mathbf{J}|=\left|\frac{\partial \varepsilon}{\partial y}\right|=|\mathbf{I}-\rho \mathbf{W}|$ Sehingga,

$f(\varepsilon)=\frac{\exp \left(-\frac{\varepsilon^{t} \varepsilon}{2 \pi^{2}}\right)}{\left(\sigma^{2} 2 \pi\right)^{n / 2}}|\mathbf{I}-\rho \mathbf{W}|$

Kemudian diperoleh fungsi kemungkinan dan fungsi $\log$ kemungkinan sebagai berikut:

$$
\begin{gathered}
\mathrm{L}\left(\beta_{;}, \rho, \sigma^{2} ; y\right)=\frac{\mid \mathrm{I}-\mathrm{pW}]}{\left(\sigma^{2} 2 \pi\right)^{n / 2}} \exp \left(-\frac{\varepsilon^{\prime} \varepsilon}{2 \pi^{2}}\right) \\
\ln \left(\beta, \rho, \sigma^{2} ; y\right)=\ln |\mathrm{I}-\rho \mathrm{W}|-\frac{n}{2} \ln \left(\sigma^{2}\right)-\frac{n}{2} \ln \left(\sigma^{2}\right)-\frac{\varepsilon^{\prime} \varepsilon}{2 \pi^{2}} \\
\ln (\mathrm{L})=-\frac{n}{2} \ln \left(2 \sigma^{2}\right)+\ln |A|-\frac{1}{2 \sigma^{2}}\left(\left(A y-Z \beta(A y-Z \beta)^{\mathrm{T}}\right)\right)
\end{gathered}
$$

Penduga $\boldsymbol{\beta}$ dan $\sigma^{2}$ diperoleh dengan memaksimumkan persamaan log kemungkinan sehingga diperoleh formula sebagai berikut:

$\boldsymbol{\beta}=\left(\mathbf{Z}^{\mathrm{T}} \mathbf{Z}\right)^{-1} \mathbf{Z}^{\mathrm{T}} \mathbf{A} \mathbf{Y}$

$$
\sigma^{2}=\frac{1}{n}(\mathbf{A Y}-\mathbf{Z} \boldsymbol{\beta})^{\mathrm{T}}(\mathbf{A Y}-\mathbf{Z} \boldsymbol{\beta})
$$

Penduga $P$ tidak dapat dilakukan dengan cara memaksimumkan persamaan log kemungkinan maksimum adanya

$|\mathbf{I}-p \mathbf{W}|$ merupakan fungsi dari parameter $\rho$, namun penduga $\rho$ dapat dilakukan secara berikut:

1. Regresikan $\mathbf{Z}$ dan $\mathbf{y}$ dengan menggunakan metode kuadrat kecil (MKT) sehingga diperoleh $\widehat{\boldsymbol{\beta}_{k}}=(\mathbf{Z} \mathbf{Z})$ ${ }^{1} \mathbf{Z} \mathbf{Y}$

2. Hitung galat yang dihasilkan oleh penduga $\widehat{\boldsymbol{\beta}_{k}}$ dengan formula sebagai berikut:

$$
\boldsymbol{\varepsilon}_{k}=\mathbf{Y}-\mathbf{Z} \widehat{\boldsymbol{\beta}_{k}}
$$

3. Regresikan Wy dan $\mathrm{Z}$ dengan menggunakan metode kuadrat terkecil (MKT) sehingga diperoleh $\widehat{\boldsymbol{\beta}_{d}}=(\mathbf{Z} \mathbf{Z})^{-1} \mathbf{Z} \mathbf{W Y}$

4. Hitung galat yang dihasilkan oleh penduga $\widehat{\boldsymbol{\beta}_{d}}$ dengan formula sebagai berikut:

$$
\varepsilon_{d}=\mathbf{Y}-\mathbf{Z} \widehat{\boldsymbol{\beta}_{d}}
$$


5. Hitung nilai penduga $\rho$ secara iterasi numerikyang memaksimumkan fungsi sebagai berikut ini:

$$
\begin{aligned}
& f(\rho)=c-\frac{n}{2} \ln \left\{\left(\boldsymbol{\varepsilon}_{k}-\hat{\rho} \boldsymbol{\varepsilon}_{d}\right)^{\mathrm{T}} \cdot\left\{\left(\boldsymbol{\varepsilon}_{k}-\hat{\rho} \boldsymbol{\varepsilon}_{d}\right)\right\}+\ln |\mathbf{I}-\rho \mathbf{W}|\right. \\
& \text { dengan, } \boldsymbol{\varepsilon}_{k}=\boldsymbol{y}-\boldsymbol{Z} \widehat{\boldsymbol{\beta}} \boldsymbol{\beta}_{k}, \boldsymbol{\varepsilon}_{\boldsymbol{d}}=\boldsymbol{y}-\boldsymbol{Z} \widehat{\boldsymbol{\beta}}, \text { dan } \mathrm{c}=-\frac{n}{2} \ln (2 \pi)-\frac{n}{2} \ln (n)-\frac{1}{2}
\end{aligned}
$$

\subsection{Anak Putus Sekolah (APS)}

Anak Putus sekolah didefinisikan sebagai mereka yang pernah bersekolah di salah satu tingkat pendidikan, tetapi pada saat survey berlangsung mereka tidak terdaftar di salah satu tingkat pendidikan formal (Septiana \& Wulandari, 2012). Anak-anak yang putus sekolah disebabkan oleh banyak faktor, sebagian besar karena faktor demografi, geografi, sosial budaya, dan ekonomi. Disamping itu dikarenakan anak putus sekolah setiap wilayah berbeda-beda.

Penelitian mengenai faktor-faktor penyebab anak putus sekolah telah banyak dilakukan. Penelitian yang dilakukan oleh Grahacendikia (2009) mengenai anak putus sekolah di Kecamatan Jangka Kabupaten Bireuen, Aceh Utara. Hasil penelitian ini menunjukkan bahwa faktor penyebab anak putus sekolah di wilayah itu adalah faktor demografi, geografi, sosial budaya, dan ekonomi. Penelitian Alifianto (2008) mengenai anak putus sekolah di Kecamatan Selangit, Kabupaten Musi Rawas, Sumatera Selatan, menemukan bahwa anak putus sekolah disebabkan oleh faktor jarak rumah ke sekolah yang jauh (faktor geografi), karena tidak ada biaya dan bekerja (faktor ekonomi), malas dan nakal, takut terhadap guru, tidak naik kelas, dan kondisi keluarga yang bermasalah (sosial budaya). Penelitian Elfindri (2001) tentang anak putus sekolah di Sumatera Barat menemukan bahwa sebagai faktor utama penyebab anak putus sekolah adalah rumah tangga yang jauh dari fasilitas publik, rumah tangga yang tidak memiliki fasilitas lampu, sehingga pendidikan orang tua yang rendah. Sedangkan penelitian yang sama oleh Septiana \& Wulandari (2013) anak putus sekolah di Jawa Timur lebih didominasi oleh faktor ekonomi yang dimana anak tersebut keluarganya miskin dan demografi yang dimana letak rumah jauh dari akses sekolah. Dalam penelitian ini yang dimaksud dengan APS adalah anak yang putus sekolah yang mengikuti ujian paket $\mathrm{C}$ karena adanya pendidikan wajib belajar.

\section{Metode Penelitian}

Metode penelitian yang akan digunakan sebagai langkah-langkah pada penelitian ini akan dijelaskan sebagai berikut:

1. Melakukan eksplorasi data untuk mengetahui informasi awal atau Gambaran umum yang bermanfaat dari data tanpa mengambil kesimpulan secara umum. Tahaan eksplorasi dilakukan untuk mengetahui perbandingan nilai peubah respon dan peubah prediktor antar kecamatan yang meliputi nilai minimum, maksimum, dan rata-rata.

2. Menentukan peubah-peubah penjelas yang digunakan dalam pendugaan model seperti rasio murid sekolah (X1), rasio guru sekolah (X2), angka buta huruf (X3), tingkat kemiskinan (X4), dan jumlah sekolah (X5).

3. Melakukan analisis regresi klasik dan pemeriksaan asumsi untuk mengetahui apakah data memenuhi asumsi untuk dilakukan analisis regresi spasial. Model Regresi Klasik dapat digunakan untuk melihat hubungan antara APS setiap Kecamatan di kota Makassar dengan faktor-faktor yang berpengaruh terhadap APS yang mengikuti ujian Paket C. Kemudian dilakukan pengujian secara serentak dan parsial untuk mengetahui peubah-peubah yang sigifikan. Peubah terikat yang digunakan adalah APS untuk mengikuti ujian Paket C (Y).

4. Menentukan pembobot spasial (W) yaitu K-Nearest Neighbor. Seperti sebagai berikut:

\begin{tabular}{llllllllllllllll}
\multicolumn{2}{c}{$[, 1]$} & {$[, 2]$} & {$[, 3]$} & {$[, 4]$} & {$[, 5]$} & {$[, 6]$} & {$[, 7]$} & {$[, 8]$} & {$[, 9]$} & {$[, 10]$} & {$[, 11]$} & {$[, 12]$} & {$[, 13]$} & {$[, 14]$} \\
{$[1]$} & 0.00 & 0.25 & 0.25 & 0.25 & 0.25 & 0.00 & 0.00 & 0 & 0.00 & 0.00 & 0.00 & 0.00 & 0.00 & 0.00 \\
{$[2]$} & 0.25 & 0.00 & 0.25 & 0.25 & 0.00 & 0.00 & 0.00 & 0 & 0.25 & 0.00 & 0.00 & 0.00 & 0.00 & 0.00 \\
{$[3]$} & 0.25 & 0.25 & 0.00 & 0.25 & 0.25 & 0.00 & 0.00 & 0 & 0.00 & 0.00 & 0.00 & 0.00 & 0.00 & 0.00 \\
{$[4]$} & 0.00 & 0.00 & 0.25 & 0.00 & 0.25 & 0.00 & 0.25 & 0 & 0.00 & 0.00 & 0.00 & 0.25 & 0.00 & 0.00 \\
{$[5]$} & 0.25 & 0.00 & 0.00 & 0.25 & 0.00 & 0.25 & 0.25 & 0 & 0.00 & 0.00 & 0.00 & 0.00 & 0.00 & 0.00 \\
{$[6]$} & 0.00 & 0.00 & 0.00 & 0.25 & 0.25 & 0.00 & 0.25 & 0 & 0.25 & 0.00 & 0.00 & 0.00 & 0.00 & 0.00 \\
{$[7]$} & 0.00 & 0.00 & 0.00 & 0.25 & 0.25 & 0.25 & 0.00 & 0 & 0.25 & 0.00 & 0.00 & 0.00 & 0.00 & 0.00
\end{tabular}




\begin{tabular}{|c|c|c|c|c|c|c|c|c|c|c|c|c|c|}
\hline [8] 0.00 & 0.00 & 0.00 & 0.00 & 0.25 & 0.25 & 0.25 & 0 & 0.25 & 0.00 & 0.00 & 0.00 & 0.00 & 0.00 \\
\hline [9] 0.00 & 0.00 & 0.00 & 0.25 & 0.00 & 0.25 & 0.25 & 0 & 0.00 & 0.00 & 0.00 & 0.25 & 0.00 & 0.00 \\
\hline [10] 0.00 & 0.25 & 0.25 & 0.00 & 0.00 & 0.00 & 0.00 & 0 & 0.00 & 0.00 & 0.00 & 0.25 & 0.00 & \\
\hline & 0.00 & 0.00 & 0.00 & 0.00 & 0.00 & 0.25 & & 0.25 & 0.00 & 0.00 & 0.25 & 0.25 & .00 \\
\hline & 0.00 & .00 & 0.25 & 0.00 & 0.00 & 0.25 & & 0.25 & 0.25 & 0.00 & 0.00 & 0.00 & 00 \\
\hline & 0.00 & .00 & 0.00 & 0.00 & 0.00 & 0.00 & & 0.25 & 0.00 & 0.25 & 0.25 & 0.00 & .25 \\
\hline 14] 0.00 & 0.25 & 0.00 & 0.25 & 0.00 & 0.00 & 0.00 & 0 & 0.00 & 0.25 & 0.00 & 0.25 & 0.00 & 00 \\
\hline
\end{tabular}

5. Uji ketergantungan spasial atau korelasi antara pengamatan yang saling berdekatan dengan indeks moran atau Moran's I untuk masing-masing variabel. Pengujian Indeks Moran dilakukan untuk mendeteksi adanya pengaruh spasial (Autokorelasi Spatial) sehingga dapat dilakukan pemodelan spasial autokorelasi. Moran's I bertujuan untuk mengidentifikasi apakah ada dependensi spasial atau tidak

6. Uji efek spasial dilakukan dengan uji heterogenitas yaitu menggunakan uji Breusch-Pagan test (BP test) untuk masing-masing variabel. nilai uji Breunch-Pagan dalam matriks Pembobot $k$ tetangga ( $k$-Nearest Neighbor, $k N N$ ) yang digunakan yaitu $\mathrm{BP}=1,61<X_{p}^{2}=7,81$ dan Nilai P-value $=0,90$ lebih besar dari $\alpha$ sebesar 0,05

7. Melakukan pendugaan dan pengujian parameter.

a.Model SAR

Model spasial yang terbentuk jika $\rho \neq 0 \lambda=0$, dinyatakan dalam bentuk:

$$
\mathbf{Y}=\rho \mathbf{W Y}+\mathbf{X} \boldsymbol{\beta}+\boldsymbol{\varepsilon}
$$

Dengan $\rho$ merupakan koefisien lag spasial d龟 merupakan vektor sisaan dan $\boldsymbol{\varepsilon} \sim N\left(0, \sigma^{2} \mathbf{I}\right)$.

Pendugaan

$\boldsymbol{\beta}$ parameter model SAR dilakukan dengan metode kemungkinan maksimum adalah sebagai berikut:

b.Model SDM

$$
\widehat{\boldsymbol{\beta}}=\left(\boldsymbol{X}^{T} \boldsymbol{X}\right)^{-1} \mathbf{X}^{\mathrm{T}}([\mathbf{I}-\rho \mathbf{W}] \mathbf{Y})
$$

Model spasial yang terbentuk jika $\rho \neq 0 \lambda=0$, dinyatakan dalam bentuk:

$$
\mathbf{Y}=\rho \boldsymbol{W} \mathbf{Y}+\boldsymbol{\beta}_{0}+\mathbf{X} \boldsymbol{\beta} 1+\boldsymbol{W} \mathbf{X} \boldsymbol{\beta} 2+\boldsymbol{\varepsilon}
$$

Pendugaan $\boldsymbol{\beta}$ parameter model SDM dilakukan dengan metode kemungkinan maksimum adalah sebagai berikut:

$$
\boldsymbol{\beta}=\left(\mathbf{Z}^{\mathrm{T}} \mathbf{Z}\right)^{-1} \mathbf{Z}^{\mathrm{T}} \mathbf{A Y}
$$

8. Interpretasi hasil analisis SAR Durbin.

\section{Hasil dan Pembahasan}

\subsection{Eksplorasi Data}

Anak Putus Sekolah (APS) yaitu anak yang sudah berhenti di sekolah formal tetapi dapat mengikuti ujian paket C atau mendaftar di sekolah Non-formal. Anak Putus Sekolah (APS) yang mengikuti ujian Paket C menunjukkan Kecamatan Mariso terdapat 198 anak, Kecamatan Tamalate 114 anak, Kecamatan Mamajang 3 anak, Kecamatan Makasar 92 anak, Kecamatan Ujung Pandang 37 anak, Kecamatan Wajo 504 anak, Kecamatan Bontoala 56 anak, Kacamatan Ujung Tanah 123 anak, Kecamatan Tallo 131 anak, Kecamatan Rappocini 60 anak, Kecamatan Tamalanrea 23 anak, Kecamatan Panakkukang 19 anak, Kecamatan Biringkanaya 21 anak, dan Kecamatan Manggala 290 anak. 


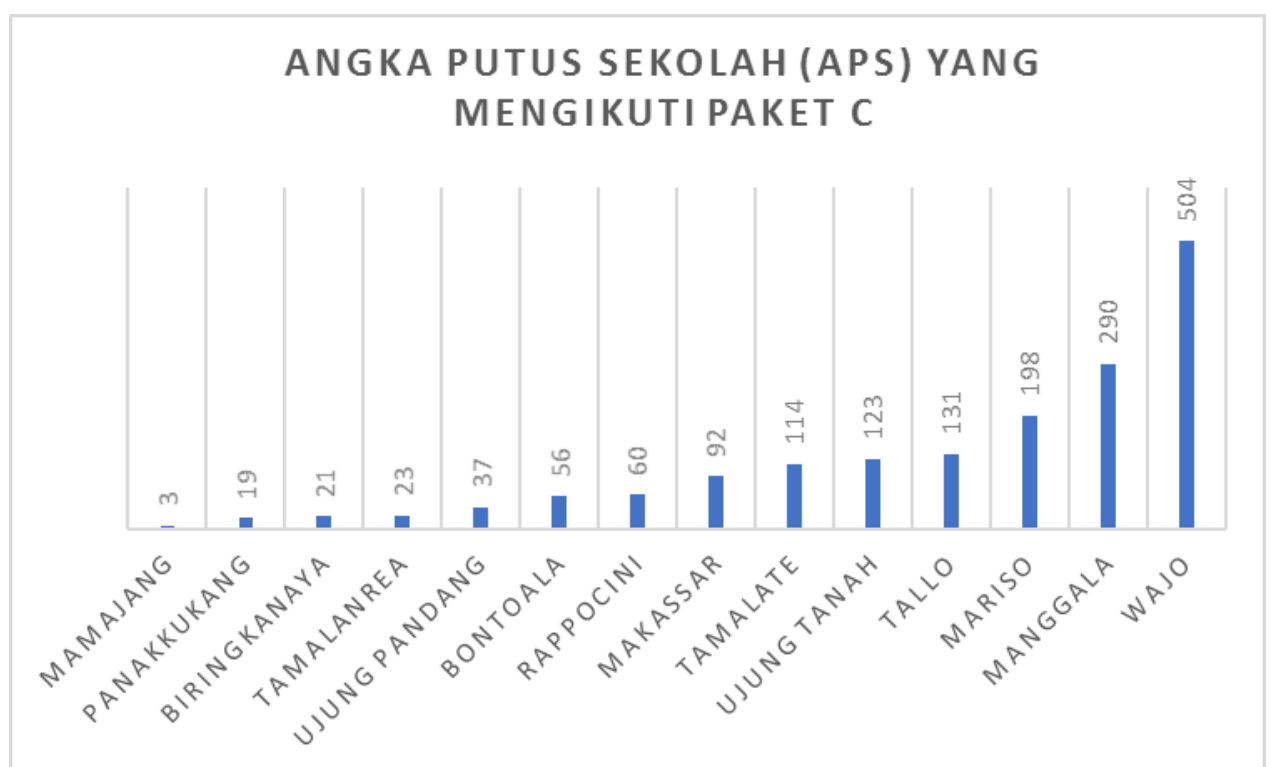

Gambar 1 Anak Putus Sekolah di setiap Kecamatan di Kota Makassar pada Tahun 2018/2019

Hasil dari Tabel 1 menunjukkan bahwa jumlah responden $(\mathrm{N})$ ada 14 kecamatan, dari 14 kecamatan ini siswa yang mengikuti ujian paket $\mathrm{C}$ dengan jumlah terkecil (minimum) yaitu 3 anak di kecamatan Mamajang, dan siswa yang mengikuti ujian paket $\mathrm{C}$ dengan jumlah terbanyak (maksimum) yaitu 504 anak di kecamatan Wajo. Dengan rata-rata (mean) sebesar 119 dengan Standar Deviasi sebesar 136. Terdapat berbagai macam jumlah siswa yang masih sekolah dibandingkan dengan jumlah sekolah dengan jumlah terkecil (minimum) yaitu $2,45 \%$ terdapat di kecamatan Mamajang dan jumlah terbanyak (maksimum) yaitu 55,39\% terdapat di kecamatan Wajo. Dengan rata-rata (mean) sebesar 16,355\% dengan Standar Deviasi sebesar 12,977\%. Terdapat berbagai macam jumlah guru yang masih mengajar di sekolah berbanding dengan jumlah sekolah dilihat dari jumlah terkecil (minimum) yaitu 6,02\% pada kecamatan Mamajang sedangkan jumlah terbanyak (maksimum) yaitu 21,09\% di kecamatan Mariso. Dengan rata-rata (mean) sebesar 15,599\% dengan Standar Deviasi sebesar 3,824\%. Terdapat anak yang rata-rata buta huruf atau tidak dapat membaca disetiap kecamatan jumlah terkecil (minimum) yaitu 3,01\% pada kecamatan Mamajang, dan jumlah terbanyak (maksimum) yaitu 15,55\% di kecamatan Wajo. Dengan rata-rata (mean) sebesar 17,426 dengan Standar Deviasi sebesar 8,216. Terdapat anak dibawah rata-rata standar atau bisa dikatakan tidak mampu (miskin) disetiap kecamatan jumlah terkecil (minimum) yaitu 14,08\% pada kecamatan Makassar, dan jumlah terbanyak (maksimum) yaitu 55,86\% di kecamatan Wajo. Dengan rata-rata (mean) sebesar 36,744\% dengan Standar Deviasi sebesar 11,590\%. Dan terdapat Jumlah Sekolah jenjang SMA atau SMK sederajat disetiap kecamatan jumlah terkecil (minimum) yaitu 7 sekolah pada kecamatan Mariso, dan jumlah terbanyak (maksimum) yaitu 30 sekolah di kecamatan Biringkanaya. Dengan rata-rata (mean) sebesar 17,786 dengan Standar Deviasi sebesar 7,886.

Tabel 1 Hasil deskripsi dari beberapa faktor yang mempengaruhi APS dari 14 kecamatan di Kota Makassar

\begin{tabular}{ccccc}
\hline Peubah & Minimum & Maksimum & Mean & Variansi \\
\hline $\boldsymbol{Y}$ & 3 & 504 & 119,357 & 136,176 \\
$\boldsymbol{X}_{\boldsymbol{I}}$ & 2,45 & 55,39 & 16,355 & 12,977 \\
$\boldsymbol{X}_{\mathbf{2}}$ & 6,02 & 21,09 & 15,599 & 3,824 \\
$\boldsymbol{X}_{\mathbf{3}}$ & 3,01 & 34,03 & 17,426 & 8,216 \\
$\boldsymbol{X}_{\boldsymbol{4}}$ & 14,08 & 55,86 & 36,744 & 11,590 \\
$\boldsymbol{X}_{\boldsymbol{5}}$ & 7 & 30 & 17,786 & 7,886 \\
\hline
\end{tabular}




\subsection{Model Regresi Klasik}

Model Regresi Klasik dapat digunakan untuk melihat hubungan antara APS setiap Kecamatan di kota Makassar dengan faktor-faktor yang berpengaruh terhadap APS yang mengikuti ujian Paket C. Kemudian dilakukan pengujian secara serentak dan parsial untuk mengetahui peubah-peubah yang sigifikan. Peubah terikat yang digunakan adalah APS untuk mengikuti ujian Paket C (Y).

Tabel 2 Pengujian Regresi Klasik

\begin{tabular}{lcccl}
\hline & Estimate & Standar of Error & t value & $\operatorname{Pr}(>|\mathbf{t}|)$ \\
\hline$X_{1}$ & 47,647 & 106,914 & 0,446 & 0,668 \\
$X_{2}$ & 8,149 & 1,968 & 4,140 & 0,003 \\
$X_{3}$ & 1.888 & 5,649 & 0,334 & 0,747 \\
$X_{4}$ & 1,713 & 4,213 & 0,407 & 0,695 \\
$X_{5}$ & 0,874 & 2,213 & 0,395 & 0,703 \\
\hline
\end{tabular}

Hasil dari Tabel 2 menjelaskan bahwa nilai statistik uji untuk semua parameter pada taraf nyata $(\alpha)$ sebesar 5\%. Maka peubah predikator yang berpengaruh nyata terhadap APS yang mengikuti ujian Paket C di Kota Makassar adalah persentase Rasio sekolah Murid $\left(X_{1}\right)$ dan Jumlah Sekolah $\left(X_{5}\right)$ dilihat dari niai $\operatorname{Pr}(>|t|)<0.05$.

Model yang terbentuk adalah sebagai berikut:

$$
\mathrm{Y}=47,647+8,149 \mathrm{X}_{1}-4,990 \mathrm{X}_{5} .
$$

Berdasarkan model yang terbentuk menunjukkan bahwa Rasio Murid Sekolah, $\left(\mathrm{X}_{1}\right)$ dan Jumlah Sekolah $\left(\mathrm{X}_{5}\right)$ memiliki hubungan atau bisa dikatakan saling memoengaruh dengan Anak Putus Sekolah (APS) yang mengikuti ujian Paket C. Artinya dengan meningkatnya Rasio Sekolah Murid sebesar satu persen, maka akan meningkatkan persentase Anak Putus Sekolah (APS) yang mengikuti ujian Paket C suatu kecamatan sebesar 8,149 persen. Selanjutnya menurunnya Jumlah Sekolah sebesar satu persen, maka akan meningkatkan persentase Anak Putus Sekolah (APS) yang mengikuti ujian Paket C suatu kecamatan sebesar 4,990 persen.

Tabel 3 Pengujian secara Simultan

\begin{tabular}{lccl}
\hline & Db & F-Statistic & $\boldsymbol{p}$-Value \\
\hline Model & 13 & 12,6 & 0,001263 \\
\hline
\end{tabular}

Berdasarkan hasil pada Tabel 3 Dapat dilihat bahwa peubah penjelas secara bersama-sama dapat mempengaruhi APS yang mengikuti ujian Paket $C$ dilihat dari nilai $F_{\text {hitung }}(12,6)>F_{\text {tabel }}(0,208)$ atau $p$-value lebih kecil dari $(\alpha)$ sebesar $5 \%$ atau $\alpha=0.05$.

\subsection{Model Autoregresif Spasial (SAR)}

Model SAR dibentuk ketika peubah respon suatu wilayah dipengaruhi oleh peubah respon wilayah yang lain yang saling bersinggungan (Anselin, 1998). Model SAR berarti model regresi yang dibentuk dengan melibatkan spasial lag. Tabel yang disajikan pada Tabel 4 untuk melihat hasil autoregresif spasial. 
Tabel 4 Hasil Uji Autoregresif Spasial

\begin{tabular}{|c|c|c|c|c|}
\hline & Estimate & Standar of Error & t value & $\operatorname{Pr}(>|\mathbf{t}|)$ \\
\hline$Y$ & 58,760 & 82,099 & 0,716 & 0,474 \\
\hline$X_{1}$ & 7,661 & 1,815 & 4,222 & $2,423 \times 10^{-5}$ \\
\hline$X_{2}$ & 1,333 & 4,377 & 0,305 & 0,761 \\
\hline$X_{3}$ & 1,901 & 3,198 & 0,594 & 0,552 \\
\hline$X_{4}$ & 0,341 & 2,018 & 0,169 & 0,866 \\
\hline$X_{5}$ & 5,106 & 1,621 & 3,150 & 0,002 \\
\hline$W Y$ & $-0,137$ & 0,283 & 0,176 & 0,677 \\
\hline
\end{tabular}

Berdasarkan Tabel 4 diperoleh nilai p-value SAR bernilai 0,677 yang dimana nilai signifikansi menggunakan $(a)=0,05$, dilihat nilai $p$-value untuk $\mathrm{X}_{1}$ sebesar 0,000002423 artinya dengan meningkatnya Rasio Sekolah Murid sebesar satu persen, maka akan meningkatkan persentase Anak Putus Sekolah (APS) yang mengikuti ujian Paket C suatu kecamatan yang saling berpengaruh antara wilayah satuan dengan wilayah satuan lainnya, $p$-value untuk $\mathrm{X}_{5}$ sebesar 0,002 artinya menurunnya Jumlah Sekolah sebesar satu persen, maka akan meningkatkan persentase Anak Putus Sekolah (APS) yang mengikuti ujian Paket $C$ suatu kecamatan yang saling berpengaruh antara wilayah satuan dengan wilayah satuan lainnya.

Diperoleh persamaan sebagai berikut:

$$
\ddot{y}=58,76-0,137 \mathrm{WY}+7,66 X_{1}-5,11 X_{5}
$$

Dari Tabel 4 dapat disimpulkan bahwa koefisien $\rho$ sebesar 0,137 nyata dengan nilai $p$-value $<0,05(\alpha)$ artinya terdapat pengaruh spasial atau lokasi yang berdekatan akan berpengaruh terhadap pengamatan sebesar $-0,137$. Misalnya Kecamatan Mariso, Kecamatan Tamalate ,Kecamatan Mamajang, Kecamatan Makassar, Kecamatan Ujung Pandang. Begitu pula dengan peubah Rasio Murid Sekolah $\left(\mathrm{X}_{1}\right)$ dan Jumlah Sekolah nyata dalam statistik dilihat dari nilai $p$-value $<0,05(\alpha)$, artinya peubah- peubah tersebut memberikan pengaruh tersebut terhadap Anak Putus Sekolah (APS) yang mengikuti ujian Paket C.

\subsection{Model Spasial Durbin}

Hasil pengujian Indeks Moran terhadap peubah prediktor yang digunakan dengan menggunakan pembobot $k$ tetangga ( $k$-Nearest Neighbor,kNN) diperoleh bahwa sebagian besar peubah terdapat korelasi spasial peubah $\mathrm{X}_{1}$ dan $\mathrm{X}_{5}$. Hasil nilai Indeks Moran pada seluruh peubah responden lebih dari nilai harapan yang menunjukkan pola data yang mengelompokkan dan memiliki kesamaan karakteristik pada wilayah yang berdekatan.

Identifikasi dengan menggunakan nilai Moran's I untuk setiap peubah menunjukkan bahwa depedensial antara lokasi yang berdekatan tidak hanya terjadi pada peubah respon, namun juga terjadi pada peubah prediktor. Oleh karena itu, dilakukan analisis dengan menggunakan Model Spasial Durbin (SDM). Estimasi parameternya disajikan pada tabel sebagai berikut:

Tabel 4.5 Hasil Spasial Durbin Model (SDM)

\begin{tabular}{ccrr}
\hline Parameter & Variabel & Estimate & $\operatorname{Pr}(>|\mathbf{z}|)$ \\
\hline$\beta_{1}$ & & & \\
(intercept) & Angka Putus sekolah & 789,176 & 0,00013 \\
$X_{1}$ & Rasio Sekolah Murid & 7,635 & 4,066 \\
$X_{2}$ & Rasio Sekolah guru & 6,239 & $0,007^{*}$ \\
$X_{3}$ & Angka Buta Huruf & $-\quad 6,133$ & 3,700 \\
$X_{4}$ & Tingkat Kemiskinan & - & 0,183 \\
$X_{5}$ & Jumlah Sekolah & 4,022 & 0,891 \\
\hline
\end{tabular}




\begin{tabular}{|c|c|c|c|}
\hline & $\rho$ & -1 & 0,005 \\
\hline$\beta_{2}$ & Estimate & Standar of Eror & $\operatorname{Pr}(>|z|)$ \\
\hline Lag. $X_{1}$ & 16,761 & 3.444 & $1,131 \times 10^{-6}$ \\
\hline Lag. $X_{2}$ & 18,789 & 10,665 & 0.078 \\
\hline Lag. $X_{3}$ & 6,154 & 10,460 & 0.556 \\
\hline Lag. $X_{4}$ & $-8,879$ & 3,806 & 0.020 \\
\hline Lag. $X_{5}$ & $-\quad 9,570$ & 2,224 & $1,691 \times 10^{-5}$ \\
\hline
\end{tabular}

Berdasarkan Tabel 5 menunjukkan bahwa nilai $p$-value dari $\rho$ sebesar $0,005<\alpha=5 \%$ maka signifikan, nilai APS yang mengikuti Paket C sebesar 789,176 yang artinya jumlah anak putus sekolah(APS) yang megikuti Paket C apabila tidak terdapat faktor-faktor yang mempengaruhi APS yang mengikuti Paket $\mathrm{C}$ maka tidak signifikan dilihat dari p-valuenya seperti Rasio Sekolah Murid $\left(\mathrm{X}_{1}\right)$, Angka Buta Huruf $\left(\mathrm{X}_{3}\right)$ dan Tingkat Kemiskinan $\left(\mathrm{X}_{4}\right)$. Sedangkan yang saling berpengaruh atau signifikan yaitu Rasio Sekolah Guru $\left(\mathrm{X}_{2}\right)$ sebesar 6,239 menjelaskan jika rasio sekolah guru di suatu kecamatan naik satu satuan maka menaikkan jumlah anak putus sekolah di kecamatan tersebut apabila faktor lain dianggap konstan, dan untuk Jumlah Sekolah $\left(\mathrm{X}_{5}\right)$ sebesar 4,022 menjelaskan jumlah angka putus sekolah akan mengalami peneurunan jika jumlah sekolah di suatu kecamatan naik satu satuan apabila faktor lain diabaikan.

Nilai $p$-value yang signifikan sebesar 0.00083 menunjukkan adanya dependensi spasial lag pada variable jumlah anak putus sekolah dan menunjukkan adanya pengaruh letak kecamatan yang berdekatan dengan kecamatan yang diamati terhadap jumlah anak putus sekolah (APS). Dengan Lag peubah prediktor yang signifikan adalah peubah prediktor dengan pembobot ketetanggaan yang berpengaruh signifikan. Peubah yang berpengaruh signifikan ketika menggunakan pembobot ketetanggaan pada $\alpha=5 \%$ dan $\alpha=10 \%$ dilihat dari nilai $P$-Value di antaranya Lag Rasio Sekolah Murid $\left(\mathrm{X}_{1}\right)$ sebesar 16,761, Lag Tingkat Kemiskinan $\left(\mathrm{X}_{4}\right)$ sebesar 18,789 dan Lag Jumlah Sekolah $\left(\mathrm{X}_{5}\right)$ sebesar 9,570. Sedangkan pembobot yang tidak signifikan ketetanggannya pada $\alpha=5 \%$ dan $\alpha=10 \%$ yang diliat dari nilai $p$-value di antaranya Lag Rasio Sekolah Guru ( $\left.\mathrm{X}_{3}\right)$, dan Lag Angka Buta Huruf $\left(\mathrm{X}_{4}\right)$, sehingga diperoleh persamaan sebagai berikut:

$\hat{y}=789,18-1 W Y-6,24 X_{2}-4,02 X_{5}+16,76 W X_{1}-8,88 W X_{4}-9,57 W X_{5}$

Dari Tabel 5 dapat disimpulkan bahwa koefisien $\rho$ sebesar 1, yang artinya terdapat dependensi spasial lag atau terdapat pengaruh letak/lokasi yang berdekatan yang berpengaruh terhadap pengamatan pada peubah Anak Putus Sekolah (APS) yang mengikuti ujian Paket $\mathrm{C}$, dan $\mathrm{W}_{\mathrm{ij}}$ menunjukkan adanya pengaruh Anak Putus Sekolah (APS) di setiap Kecamatan yang berdekatan $(j)$ dengan Anak Ptus Sekolah (APS) disetiap Kecamatan yang diamati $(i)$ terhadap yang mengikuti ujian Paket C Misalnya Kecamatan Mariso, Kecamatan Tamalate, Kecamatan Mamajang, Kecamatan Makassar, Kecamatan Ujung Pandang. Koefisien parameter $\beta_{22}$ sebesar $-6,24, \beta_{25}$ sebesar $-0,42$, $\mathrm{WX}_{1}$ sebesar 16,76, $\mathrm{WX}_{4}$ sebesar $-8,88, \mathrm{WX}_{5}$ sebesar $-9,57$ dengan nilai $P$-value dari $\rho<0,05(\alpha)$ atau signifikasi dari peubah Rasio Sekolah Guru $\left(\mathrm{X}_{2}\right)$, Jumlah Sekolah $\left(\mathrm{X}_{5}\right)$ berpengaruh terhadap Anak Putus Sekolah (APS) yang mengikuti ujian Paket C. Pengaruh Lag Spasialnya seperti Lag. Rasio Sekolah Murid ( $\left.\mathrm{X}_{1}\right)$, Lag. Tingkat Kemiskinan $\left(\mathrm{X}_{4}\right)$ dan Lag. Jumlah Sekolah $\left(\mathrm{X}_{5}\right)$.

\subsection{Pembahasan}

Setelah melihat parameter signifikan pada analisis diatas maka di dapatkan dua variable signifikan yang berpengaruh terhadap variable remaja putus sekolah yang mengikuti ujian Paket C usia SMA dikota Makassar. Variabel prediktor yang signifikan adalah Rasio Sekolah Guru $\left(\mathrm{X}_{2}\right)$ dan Jumlah Sekolah $\left(\mathrm{X}_{5}\right)$.

Hal ini berdasarkan adanya lag variabel independen yang signifikan yaitu lag Rasio Sekolah Murid $\left(\mathrm{X}_{1}\right)$, lag Tingkat Kemiskinan $\left(\mathrm{X}_{4}\right)$ dan lag Jumlah Sekolah $\left(\mathrm{X}_{5}\right)$. Sehingga menyebabkan hasil estimasi parameter menggunakan SDM menjadi signifikan dan pada nilai Moran's I mengidentifikasikan adanya dependensi spasial pada variabel independen yang artinya ada kemiripan sifat untuk lokasi yang saling berdekatan.

Kriteria yang digunakan untuk memilih model adalah nilai AIC. Nilai AIC dapat dilihat pada tabel sebagai berikut: 
Tabel 6 Perbandingan Nilai AIC dan P seudo $\mathrm{R}^{2}$

\begin{tabular}{ccc}
\hline Model & SAR & SDM \\
\hline AIC & 161,55 & 142,39 \\
P Seudo R2 & 0,89 & 0,99 \\
\hline Keputusan & - & Terpilih \\
\hline
\end{tabular}

Berdasarkan hasil Tabel 6 menunjukkan bahwa mendapatkan model terbaik apabila nilai AIC lebih kecil. Nilai AIC yang lebih kecil terdapat di model Spasial Durbin. sehingga model yang dipilih untuk APS yang mengikuti ujian Paket C adalah Model Spasial Durbin (SDM) dilihat dari nilai AIC yaitu 142,39.

\section{Kesimpulan}

Berdasarkan hasil analisa dan pembahasan dapat diambil beberapa kesimpulan tentang angka putus sekolah (APS) yang mengikuti ujian Paket C usia SMA di Kota Makassar, yaitu :

1) Berdasarkan hasil analisis pada APS yang mengikuti ujian Paket C tingkat SMA di Kota Makassar terdapat dependensi spasial antar kecamatan satu dengan kecamatan satuan lainnya. Adapun deskripsi Angka Putus Sekolah (APS) di Kota Makassar adalah nilai minimum di Kecamatan Mamajng yaitu 3 orang dan nilai terbesar di Kecamatan Wajo yaitu 504 orang. Dengan rata-rata APS sebesar 119 dengan standar deviasi sebesar 136.

2) Berdasarkah hasil analisis SAR Durbin pada APS yang mengikuti ujian Paket C tingkat SMA sederajat di Kota Makassar, maka modelnya sebagai berikut:

$$
\hat{y}=789,18-1 W Y-6,24 X_{2}-4,02 X_{5}+16,76 W X_{1}-8,88 W X_{4}-9,57 W X_{5}
$$

3) Faktor -faktor yang mempengaruhi APS yang mengikuti ujian Paket $\mathrm{C}$ dengan hasil analisis SDM didapatkan variabel prediktor yang signifikan pada $\alpha=5 \%$ yang dilihat dari nilai $P$-value adalah Rasio Guru Sekolah (X2) dan Jumlah Sekolah (X5). Dan Parameter Lag spasial yang didapatkan variabel prediktor yang signifikan pada $\alpha$ = 5\% yang dilihat dari nilai P-Value yaitu Lag Rasio Murid Sekolah (X1), Lag Tingkat Kemiskinan (X4) dan Lag Jumlah Sekolah (X5).

\section{References}

Anselin, L. (1988). Spatial Econometrics : Methods and Models. Dordrecht: Kluwer Academic Publishers.

Anselin, L.(1998). GIS Research Infrasture for Spatial Analysis of Real Estate Markets. Journal of Housing Research 1998, Vol 9 no. 1, PP 113-133.

Anselin, L. (1999), Spatial Econometrics, University of Texas, Dallas.

Alifianto, (2008). Kondisi Psikologi Anak Putus Sekolah (APS). Tesis Universitas Wijayakusuma Purwokerto

Asfar, (2016). Studi Penentuan Matriks Pembobot Spasial Optimum Dalam Pendugaan Area Kecil. Tesis Sekolah Institut Pertanian Bogor (IPB).

Badan Pusat Statistik (2016). Statistik Pendidikan Provinsi Sulawesi Selatan 2016). Jakarta.

Choiriyah, N.I. (2009). Karakterisitik Siswa Putus Sekolah Tingkat SD dan SMP di Kawasan Surabaya Utara. [Tugas Akhir]. Surabaya: Program Sarjana Jurusan Statistika ITS.

Dinas Pendidikan (2019). Anak Putus Sekolah (APS) yang mengikuti Ujian Paket C (2018-2019). Kota Makassar.

Devitasari, E. (2017). Tingginya Anak Putus Sekolah di Jawa Tengah Karena Kepadatan Penduduk. Jurnal Gaussian Semarang, Vol : 3(5) hal :57-66.

Elfindri, (2001). Strategi Sukses Membangun Daerah. Gorga Media. Jakarta

Grahacendikia, (2009). Anak Putus Sekolah di Kecamatan Jangka Kabupaten Bireun Provinsi Nanggroe Aceh Darussalam Dengan Menggunakan Metode Spasial Durbin. Jurnal Keperawatan Yogyakarta, Vol : 2 (4) hal : 125-135. 
Halim., S., Anastasya, S., Evalina, A., \& Tobing, A. F. (2008). Penentuan harga jual hunian pada apartemen di Surabaya dengan menggunakan metode regresi spasial. Jurnal Teknik Industri 10(2): hal. 151-157.

Kemdikbud, (2017). Data dan Informasi Pendidikan. Indonesia: Jakarta

LeSage, J. P. (1999). The Theory and Practice of Spatial Econometrics. Toledo:Departement of Economics University of Toledo.

Nugroho. S, (2016). Kajian Spatial Durbin (SDM) untuk menelaah faktor - faktor yang mempengaruhi nilai Ujian Nasional (UN) Di Madrasah Aliyah Negeri (MAN) Di Pulau Jawa tahun 2014 -2015. Tesis Sekolah Institut Pertanian Bogor (IPB).

Septiana, L. dan Wulandari, P.S. (2009). Pemodelan Remaja Putus Sekolah Usia SMA di Provinsi Jawa Timur dengan Menggunakan Metode Regresi Spasial. digilib.its.ac.id/public/ITS-Undergraduate-16199-Cover_id-pdf.pdf.

Taryono, A. P. N, Ispriyanti, I, \& Prahutama, A. (2018). Analisis faktor - faktor yang mempengaruhi penyebaran Demam Berdarah Dengue (DBD) di provinsi Jawa Tengah dengan Metode Spatial Autoregressive Model dan Spatial Durbin Model. Indonesia Journal of Applied Statistics. Vol 1(2). Hal: 1-13.

UU Sisdiknas, (2003) . Sistem Pendidikan Nasional. Indonesia: Jakarta 